\title{
Isolasi DNA dari Bercak Urine Manusia sebagai Bahan Alternatif Pemeriksaan Identifikasi Personal
}

\author{
Ahmad Yudianto ${ }^{1,2,3}$, dan Yeti Eka Sispitasari² \\ ${ }^{1}$ Departemen Ilmu Kedokteran Forensik \& Medikolegal, Fakultas Kedokteran, Universitas Airlangga \\ 2 Program Studi Magister Ilmu Forensik, Sekolah Pascasarjana, Universitas Airlangga \\ ${ }^{3}$ Human Genetic Studi Group Institute of Tropical Disease, Universitas Airlangga
}

Korespondensi: Ahmad Yudianto

Email: yudi4n6sby@yahoo.co.id

\begin{abstract}
ABSTRAK: Menentukan identitas personal dengan tepat amat penting dalam penyidikan karena adanya kekeliruan dapat berakibat fatal dalam proses peradilan. Identifikasi melalui analisa DNA melibatkan kromosom somatik maupun mtDNA. Setiap bagian tubuh manusia dapat diambil sebagai spesimen karena setiap sel berinti dalam tubuh seseorang memiliki rangkaian DNA identik. Selama ini sampel yang sering digunakan dalam identifikasi melalui analisa DNA adalah bercak darah, bercak sperma, dan tulang, sedangkan pada kasus tertentu yang menyebabkan keluar urine pada pakaian sering diabaikan. Sejauh ini identifikasi personal melalui bercak urine dengan metode analisis DNA belum banyak dilakukan. Penelitian ini menunjukkan, lama waktu paparan yakni hari ke-1, 7, dan 14 terhadap lokus: CTT dan amelogenin 106 bp-112 bp. Semua sampel dalam visualisasi hasil PCR dengan silver staining PAGE nampak band (terdeteksi). Namun pada lama waktu paparan hari ke-20 didapat hanya lokus THO1 dan TPOX semua sampelnya (100\%) nampak band (terdeteksi), sedangkan lokus CSF1PO dan amelogenin 50\% nampak jelas band. Hal ini menunjukkan bahwa pada pemeriksaan DNA bercak urine melalui deteksi lokus STR CTT didapatkan respon deteksi yang berbeda pada berbagai waktu lama paparan. Keberhasilan deteksi lokus tersebut ditunjang oleh adanya perbedaan amplicon product dan kandungan GC pada masing-masing lokus. Dari lokus-lokus yang diteliti, rasio GC content dalam primer diurut dari yang terendah adalah: lokus CSF1PO, TPOX, dan TH01. Dari penelitian ini didapatkan bahwa lokus TH01 maupun TPOX memiliki kemungkinan yang sama dalam keberhasilan pemeriksaan STR dibandingkan dengan lokus CSF1PO.
\end{abstract}

Kata kunci: isolasi DNA; bercak urine; identifikasi; STR

\begin{abstract}
Accurate determination of personal identity is crucial for an investigation since any inaccuracy may lead to fatal consequences in the judicial process. Identification through DNA analysis involves somatic chromosomes and mtDNA. Each part of the human body can be taken as a specimen since every nucleated cell in the body of an individual has identical DNA sequence. To date, samples for identification through DNA analysis are obtained from blood stains, semen stains, bones, vaginal swab, and buccal swab. In certain cases, urine stains on the clothing have frequently been overlooked. So far, personal identification through DNA analysis by the use of urine stains has not been commonly carried out. The present study detected bands in the loci of CSF1PO, THO1, TPOX, and 106 bp-112 bp amelogenin in all samples visualized from the results of PCR with PAGE-silver staining for exposure durations of 1, 7, and 14 days. However, for exposure duration of 20 days, bands were only detected in the loci of THO1 and TPOX in all samples (100\%), whereas the loci of CSF1PO and 50\% amelogenin exhibited obvious bands. These indicated that DNA analysis of urine stains through detection of the locus STR CSF1PO, THO1, TPOX exhibited different detection responses for different exposure durations. Successful detection of these loci was supported by the differences in amplicon product and GC content at each locus. Within the loci studied, the ratio of GC content of the primers was sorted from the lowest as follow: locus CSF1PO, TPOX, and THO1. In conclusion, the loci of THO1 and TPOX had the same probability of success in the STR examination compared with the locus of CSF1PO.
\end{abstract}

Keywords: DNA isolation; urine stains; identification; STR 


\section{Pendahuluan}

Identifikasi personal merupakan suatu masalah dalam kasus pidana maupun perdata. Menentukan identitas personal dengan tepat amat penting dalam penyidikan karena adanya kekeliruan dapat berakibat fatal dalam proses peradilan [1]. Identifikasi dalam kedokteran forensik diantaranya sidik jari (daktiloskopi), pemeriksaan property, medis, gigi-geligi, serologi, dan metode eksklusif. Saat ini metode identifikasi telah berkembang ke arah forensik molekuler. Forensik molekular pertama kali diperkenalkan oleh Sir Alex Jefreys pada tahun 1985, yang memanfaatkan pengetahuan kedokteran dan biologi pada tingkat molekul atau DNA (Deoxyribonucleic acid).

DNA merupakan unit keturunan terkecil dan terdapat pada semua mahluk hidup mulai dari mikroorganisme sampai organisme tingkat tinggi seperti manusia, hewan dan tanaman. Menurut Notosoehardjo [2], tiap jaringan mempunyai kandungan DNA yang berbeda-beda tergantung struktur serta komposisi selnya. Jaringan dengan banyak sel berinti dan sedikit jaringan ikat umumnya mempunyai kadar DNA tinggi. Pemilihan organ yang akan diisolasi DNA guna analisis kasus forensik sangatlah penting.

Setiap bagian tubuh manusia dapat diambil sebagai spesimen karena setiap sel yang berinti dalam tubuh seseorang memiliki rangkaian DNA identik, dimana seorang anak pada dasarnya menerima jumlah material genetika yang sama dari ibu dan ayah kandungnya (hukum pewarisan sifat dari Mendel) [3]. Selama ini spesimen (sampel) yang banyak dipakai dalam pemeriksaan DNA untuk mengidentifikasi adalah bercak darah/darah, bercak sperma, vaginal swab, buccal swab, dan tulang. Dalam kedokteran forensik, salah satu pemeriksaan yang sangat membantu penyidikan adalah pemeriksaan barang bukti yang ada di tubuh korban, pelaku kejahatan dan tempat kejadian perkara (TKP). Pelaku tindak kejahatan sering menghilangkan atau mengaburkan barang bukti pelaku atau korban, misalnya de- ngan pencucian. Pada pencucian biasanya pelaku terfokus pada bercak darah sehingga hanya bercak darah saja yang dicuci, dipotong atau dibakar. Namun demikian pada pakaian selain terdapat bercak darah juga masih ada bercak keringat yang melekat terutama pada daerah tertentu misal di kerah leher pakaian, lengan ataupun bagian ketiak pakaian. Pada kasus jerat atau gantung diri, pada umumnya didapatkan adanya kencing atau cairan mani yang keluar dari alat kelamin serta kotoran dari anus yang merupakan akibat proses mati lemas (asfiksia). Urine yang menempel pada celana atau kain sekitarnya atau dengan kata lain bercak urine tersebut seringkali diabaikan dalam pemeriksaan.

Pada penelitian sebelumnya didapatkan bahwa urine mengandung DNA inti dan DNA mitokondria. Komposisi urine mengandung sedikit sel epitel yang merupakan hasil pelepasan regular dari kandung kemih dan uretra eksternal. Berkenaan dengan komposisi tersebut, maka bercak urine pada pakaian mengandung sel somatik yang berinti sehingga dapat dilakukan ekstraksi DNAnya. Sampai saat ini di Indonesia identifikasi personal melalui bercak urine dengan metode analisis DNA (DNA profiling) belum banyak dilakukan, sehingga penelitian ini diharapkan dapat memberi jawaban pada hal-hal yang terkait dengan efektivitas penggunaan bercak urine sebagai bahan identifikasi forensik.

\section{Metode}

\subsection{Rancangan penelitian}

Penelitian ini dilakukan secara eksperimental laboratorik untuk membuktikan identifikasi melalui isolasi DNA bercak urine yang disimpan selama 1, 7, 14, dan 20 hari pada lokus CSF1PO, TH01, TPOX dan amelogenin, dengan rancangan penelitian cross sectional survey yang dilakukan di laboratorium Human Genetic Study Group, Institute of Tropical Disease UNAIR.

\subsection{Bahan}

Bahan penelitian meliputi bercak urine dari 
sukarelawan serta DNAzol reagent untuk ekstraksi DNA. Bahan untuk PCR adalah PCR Mix (12,5 $\mu \mathrm{l}$ ) yang terdiri dari dNTP (ATP, CTP, TTP, GTP), $\mathrm{MgCl}_{2}$, dan Taq Polimerase, DW Sigma (DNA atau nuclease free water), primer: CSF1PO (5'-AACCTGAGTCTGCCAAGGACTAGC-3' dan 5'-TTCCACACACCACTGGCCATCTTC-3'), THO1 (5'-CTGGGCACGTGAGGGCAGCGTCT-3' dan 5'-TGCCGGAAGTCCATCCTCACAGTC-3'), TPOX (5'-ACTGGCACAGAACAGGCATCTAGG-3' dan 5'-GGAGGAACTGGGAACCACACAGGT-3'), amelogenin X 106 bp; Y 112 bp (5'CTGATGGTTGGCCTCAAGCCTGTG-3' dan 5'TAAAGAGATTCATTAACTTGACTG-3').

\subsection{Ekstraksi DNA bercak urine dengan DNAzol reagent (Invitrogen Tech-Line ${ }^{\text {sm }}$ )}

Kain yang mengandung bercak urine dipotong, dimasukkan ke dalam tabung conical dan dicampur dengan DNA free water, selanjutnya dilakukan sonikasi selama 2-3 jam. Potongan kain lalu dikeluarkan dan cairan yang masih berada di tabung dan disentrifus (10.000 g) selama 10 menit. Pellet diambil kemudian dicampur dengan 1 $\mathrm{ml}$ DNAzol. Keduanya dicampur dengan cara vortexing lalu diinkubasi selama 5 menit pada suhu kamar. Campuran kemudian disentrifus $(10.000$ g) selama 10 menit pada suhu $4^{\circ} \mathrm{C}$, kemudian viscous supernatant diambil dan dimasukkan ke dalam tabung baru. 0,5 ml etanol absolut ditambahkan, dibolak-balik, kemudian diinkubasi selama 1-3 menit, disentrifus (4.000 g) selama 1-2 menit pada suhu $4^{\circ} \mathrm{C}$, kemudian supernatan dibuang secara hati-hati agar DNA tidak ikut terbuang. Pelet dicuci dengan 0,8-1 ml etanol 75\% sebanyak 2 kali dan setiap kali dicuci dibolakbalik selama-3-6 kali. Tabung diletakkan dengan posisi tegak selama 0,5-1 menit, setelah itu etanol $75 \%$ dibuang dengan cara pippeting atau decanting. Pellet kemudian dikeringkan dengan cara membiarkan tabung terbuka selama 5-15 detik sesudah etanol 75\% dibuang. Pellet yang berisi DNA tersebut kemudian dilarutkan dengan larutan $\mathrm{NaOH} 8 \mathrm{mM}$ sebanyak 0,2-0,3 ml, divorteks secukupnya, kemudian disimpan pada suhu $-20^{\circ} \mathrm{C}$.

\subsection{Amplifikasi PCR}

Amplifikasi DNA melalui PCR dilakukan dengan protokol sebagai berikut: CSF1PO (Gene Ampr. PCR System 9700 Thermal Cycler, Promega Corp.2001): tahap I: initial denaturation $96^{\circ} \mathrm{C}$ selama 2 menit; tahap II: siklus 1 (10 kali) yang terdiri dari subsequent denaturation $94^{\circ} \mathrm{C}$ selama 1 menit, annealing $64^{\circ} \mathrm{C}$ selama 1 menit, extension $70^{\circ} \mathrm{C}$ selama 1 menit 30 detik dan siklus 2 (20 kali) yang terdiri dari denaturation $90^{\circ} \mathrm{C}$ selama 1 menit, annealing $64^{\circ} \mathrm{C}$ selama 1 menit, extension $70^{\circ} \mathrm{C}$ selama 1 menit 30 detik; tahap III: hold step $4^{\circ} \mathrm{C}$. THO1 (Gene Ampr. PCR System 9700 Thermal Cycler, Promega Corp.2001): tahap I: initial denaturation $96^{\circ} \mathrm{C}$ selama 2 menit; tahap II: siklus 1 (10 kali) terdiri dari subsequent denaturation $94^{\circ} \mathrm{C}$ selama 1 menit, annealing $64^{\circ} \mathrm{C}$ selama 1 menit, extension $70^{\circ} \mathrm{C}$ selama 1 menit 30 detik dan siklus 2 (20 kali) terdiri dari denaturation $90^{\circ} \mathrm{C}$ selama 1 menit, annealing $64^{\circ} \mathrm{C}$ selama 1 menit, extension $70^{\circ} \mathrm{C}$ selama 1 menit 30 detik; tahap III: hold step $4^{\circ} \mathrm{C}$. TPOX (Gene Ampr. PCR System 9700 Thermal Cycler, Promega Corp.2001): tahap I: initial denaturation $96^{\circ} \mathrm{C}$ selama 2 menit; tahap II, siklus 1 (10 kali) yang terdiri dari subsequent denaturation $94^{\circ} \mathrm{C}$ selama 1 menit, annealing $64^{\circ} \mathrm{C}$ selama 1 menit, extension $70^{\circ} \mathrm{C}$ selama 1 menit 30 detik dan siklus 2 (20 kali) yang terdiri dari denaturation $90^{\circ} \mathrm{C}$ selama 1 menit, annealing $64^{\circ} \mathrm{C}$ selama 1 menit, extension $70^{\circ} \mathrm{C}$ selama 1 menit 30 detik; tahap III hold step $4^{\circ} \mathrm{C}$. Amelogenin (Promega Corp,.2001): tahap I: initial denaturation $96^{\circ} \mathrm{C}$ selama 2 menit; tahap II, siklus 1 (10 kali) yang terdiri dari subsequent denaturation $94^{\circ} \mathrm{C}$ selama 1 menit, annealing $70^{\circ} \mathrm{C}$ selama 1 menit 30 detik, extension $64^{\circ} \mathrm{C}$ selama 1 menit dan siklus 2 (20 kali) yang terdiri dari denaturation $90^{\circ} \mathrm{C}$ selama 1 menit, annealing $60^{\circ} \mathrm{C}$ selama 1 menit, extension $70^{\circ} \mathrm{C}$ selama 1 menit 30 detik; tahap III: hold step $4^{\circ} \mathrm{C}$.

\subsection{Elektroforesis}

Dalam tahap ini dengan menggunakan Polyacrylamid Agarose Composite Gel Electrophoresis (PAGE) dengan pewarnaan silver staining. Prose- 
dur PAGE (Edvotek, 2001) dilakukan sebagai berikut: agarose gel dibuat dari $30 \mathrm{ml}$ Tris Boric EDTA 0,5X dan agarose 0,15 gram, dipanaskan dalam microwave sampai jernih kemudian didinginkan sampai suhu $50^{\circ} \mathrm{C}$. Kemudian ditambah Acrylamid Bis 4,5 ml dan Temed $15 \mu \mathrm{l}$. Selanjutnya ditambahkan amonium persulfat $100 \mu \mathrm{l}$, lalu dituangkan pada cetakan (gel bed), ditunggu sampai dingin/membeku. Selanjutnya DNA hasil PCR 12,5 $\mu$ l dengan loading $2 \mu$ l dimasukkan dan di-running pada voltase 70 volt selama 2 jam.

Prosedur Silver Staining PAGE (Edvotek, 2001) yang terdiri dari: drying: (metanol 20\% + gliserol $2 \%$ ) dalam $100 \mathrm{ml}$ aquades selama 5 menit, fiksasi: (etanol 10\% + gliserol asam asetat 5\%) dalam $100 \mathrm{ml}$ aquades selama 20 menit, dicuci/ bilas dengan aquades $1 \mathrm{x}$ dengan cepat, staining: $\mathrm{AgNO}_{3}$ 0,1\% dalam aquades $100 \mathrm{ml}$ selama 50-80 menit, developing: $(\mathrm{NaOH}$ 1,5\% + Formalin 100 $\mathrm{l}$ ) dalam $100 \mathrm{ml}$ aquades, lalu dilihat di lampu sampai terlihat jelas.

\section{Hasil dan diskusi}

\subsection{Kadar DNA}

Dalam penelitian ini diawali dengan perlakuan pada sampel bercak urine, yakni pemaparan lama waktu. Adapun lama waktu paparan dalam penelitian ini: hari ke-1, 7, 14, dan 20. Kemudian dilanjutkan dengan isolasi DNA sampel bercak urine dengan metode DNAzol. Hasil isolasi DNA sampel tersebut dilanjutkan dengan pengukuran kadar DNA dengan menggunakan spektrofotometer uv-vis pada panjang gelombang $260 \mathrm{~nm}$. Hasil pengukuran kadar DNA setelah isolasi DNA dari bercak urine pada kain sebelum dilakukan amplifikasi Polymerase Chain Reaction (PCR) disajikan pada Tabel 1.

Dari Tabel 1 terlihat adanya penurunan kadar DNA dari bercak urine pada sampel yang terpapar lama waktu. Semakin lama waktu yang dipaparkan semakin turun kadar DNAnya, yakni rerata pada hari ke-1, 7, 14, dan 20 berturut-turut adalah 32,$5 ; 21 ; 16,5$; dan $14 \mu \mathrm{g} / \mathrm{ml}$. Adanya penurunan kadar DNA dalam penelitian ini menunjukkan
Tabel 1. Kadar DNA pada bercak urine

\begin{tabular}{llll}
\hline Sampel & & $\begin{array}{l}\text { Kadar } \\
(\mu \mathrm{g} / \mathrm{ml})\end{array}$ & $\begin{array}{l}\text { Rerata kadar } \\
(\mu \mathrm{g} / \mathrm{ml})\end{array}$ \\
\hline Hari ke-1 & 1 & 35 & 32,5 \\
& 2 & 30 & \\
Hari ke-7 & 1 & 20 & 21 \\
& 2 & 22 & \\
Hari ke-14 & 1 & 15 & 16,5 \\
& 2 & 18 & \\
Hari ke-20 & 1 & 13 & 14 \\
& 2 & 15 & \\
\hline
\end{tabular}

adanya pengaruh lama waktu paparan, sehingga mengakibatkan adanya kerusakan struktur DNA tersebut. Kerusakan DNA yang disebabkan oleh paparan-paparan yang abnormal contohnya temperatur yang tinggi tersebut menurut Watson [4], disebabkan oleh rusaknya ikatan hidrogen DNA yang irreversible. Kondisi ini mengakibatkan kerusakan pasangan purin-primidin pada DNA, dimana pasangan purin-primidin ini merupakan komponen utama pada struktur DNA.

Dari hasil penelitian ini membuktikan adanya pengaruh efek lingkungan dalam hal ini lama waktu paparan terhadap pengukuran kadar DNA yang terkandung. Hal tersebut terlihat dari hasil pengukuran kadar DNA melalui spektrofotometer menunjukkan penurunan kadar pada sampel bercak urine yang tersimpan di suhu kamar dan tempat dengan kelembaban tinggi dari hari ke-1, 7, 14 sampai hari ke-20 terdapat adanya penurunan. Namun dengan adanya penurunan kadar tersebut, bukan merupakan suatu hambatan sebab kadar DNA yang tersisa masih memungkinkan untuk dilakukan pemeriksaan DNA profiling yakni minimal $50 \mathrm{ng}$ [5].

Kadar minimal DNA yang dapat digunakan pada analisis DNA pada prinsipnya tergantung pada kebutuhan dan jenis pemeriksaan yang dilakukan. Pada pemeriksaan DNA forensik yang berbasis Restriction Fragment Length Polymorphism (RLFP) misalnya, kadar DNA yang dibutuhkan relatif besar yakni sekitar $100 \mathrm{ng}$, masih 'segar' dengan maksud untuk meningkatkan kemungkinan keberhasilan dalam penatalaksanaan 
DNA profiling. Menurut Notosoehardjo [5] kadar DNA minimal yang dibutuhkan pada pemeriksaan DNA forensik masing-masing sebesar $50 \mathrm{ng}$ dan 20 ng, sedangkan menurut Butler [6], kadar DNA dalam pemeriksaan STR minimal 0,5-2,5 ng. Dalam penelitian ini kadar DNA yang didapat dari sampel bercak urine antara rentang 35-15 $\mu \mathrm{g} /$ $\mathrm{ml}$, sehingga masih mencukupi untuk dilakukan pemeriksaan analisis DNA.

\subsection{Efek lama waktu paparan terhadap DNA dari bercak urine pada lokus STR CODIS (CSF1PO, THO1, TPOX dan Amelogenin)}

Hasil pemeriksaan efek lama waktu paparan terhadap DNA dari bercak urine dalam lokuslokus STR CODIS (CSFIPO, THO1, TPOX, Amelo- genin) dapat dilihat Tabel 2.

Dari Tabel 2, pada seluruh sampel dalam penelitian ini yang dilakukan pemeriksaan melalui DNA profiling pada lokus CSF1PO, THO1, TPX, dan Amelogenin dari DNA hasil isolasi dari bercak urine semua terdeteksi meskipun penampakan pita band-nya tidak sama karena adanya perlakuan. Pada lokus CSF1PO dan Amelogenin pada hari ke-20 hanya satu sampel menunjukkan pita band yang tidak nampak/samar.

Visualisasi hasil PCR dengan PAGE pada Gambar 1 menunjukkan semua sampel terdeteksi pada semua perlakuan (lama waktu) terhadap lokus TPOX (rentang antara 224 bp-252 bp) dan terhadap lokus THO1 (rentang antara 179 bp$203 \mathrm{bp}$ ).

Tabel 2. Hasil deteksi efek lama waktu penyimpanan terhadap DNA dari bercak urine dalam berbagai perlakuan lama waktu, deteksi pada lokus STR (CSF1PO, TH01, TPOX, Amelogenin)

\begin{tabular}{lllllllll}
\hline Lama waktu & CSFIPO & \multicolumn{3}{c}{ THO1 } & \multicolumn{2}{c}{ TPOX } & \multicolumn{2}{c}{ Amelogenin } \\
\cline { 2 - 9 } & T & TT & T & TT & T & TT & T & TT \\
\hline Hari 1 & 2 & 0 & 2 & 0 & 2 & 0 & 2 & 0 \\
Hari 7 & 2 & 0 & 2 & 0 & 2 & 0 & 2 & 0 \\
Hari 14 & 2 & 0 & 2 & 0 & 2 & 0 & 2 & 0 \\
Hari 20 & 1 & 1 & 2 & 0 & 2 & 0 & 1 & 1 \\
\hline
\end{tabular}

T: terdeteksi

TT: tidak terdeteksi

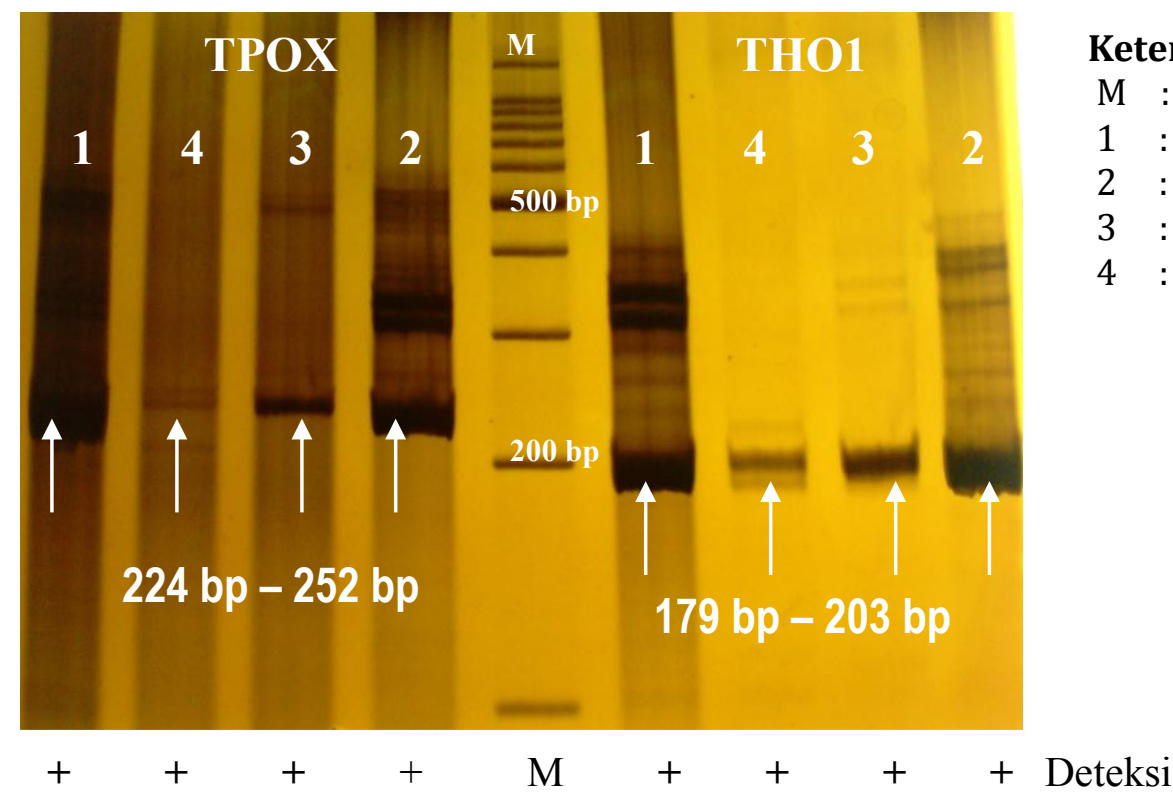

Gambar 1. Visualisasi hasil PCR lokus TPOX dan THO1 pada bercak sampel 
Visualisasi hasil PCR dengan PAGE Gambar 2, menunjukkan semua sampel terdeteksi pada semua perlakuan (lama waktu) terhadap lokus TPOX (rentang antara 224 bp-252 bp) dan terhadap lokus THO1 (rentang antara 179 bp-203 bp).

Visualisasi hasil PCR dengan PAGE Gambar 3, menunjukkan hampir semua sampel terdeteksi pada semua perlakuan (lama waktu) terhadap lokus CSF1PO (rentang antara 295 bp-327 bp) dan hanya sampel bercak hari ke-20 yang menunjukkan pita band yang tidak nampak/samar.
Visualisasi hasil PCR dengan PAGE pada Gambar 4, menunjukkan hampir semua sampel terdeteksi pada semua perlakuan (lama waktu) terhadap lokus Amelogenin (rentang antara 106 bp-112 bp) yakni pada hari ke-1, 7, 14, dan 20 keluar pita bandnya. Dalam penelitian menunjukkan pada lama waktu paparan yakni hari ke-1, 7 dan 14 pada lokus (CSF1PO, TH01, TPOX, dan Amelogenin) semua sampel dalam visualisasi hasil Polymerase Chain Reaction (PCR) dengan silver staining PAGE nampak pita/band-nya (terdetek-

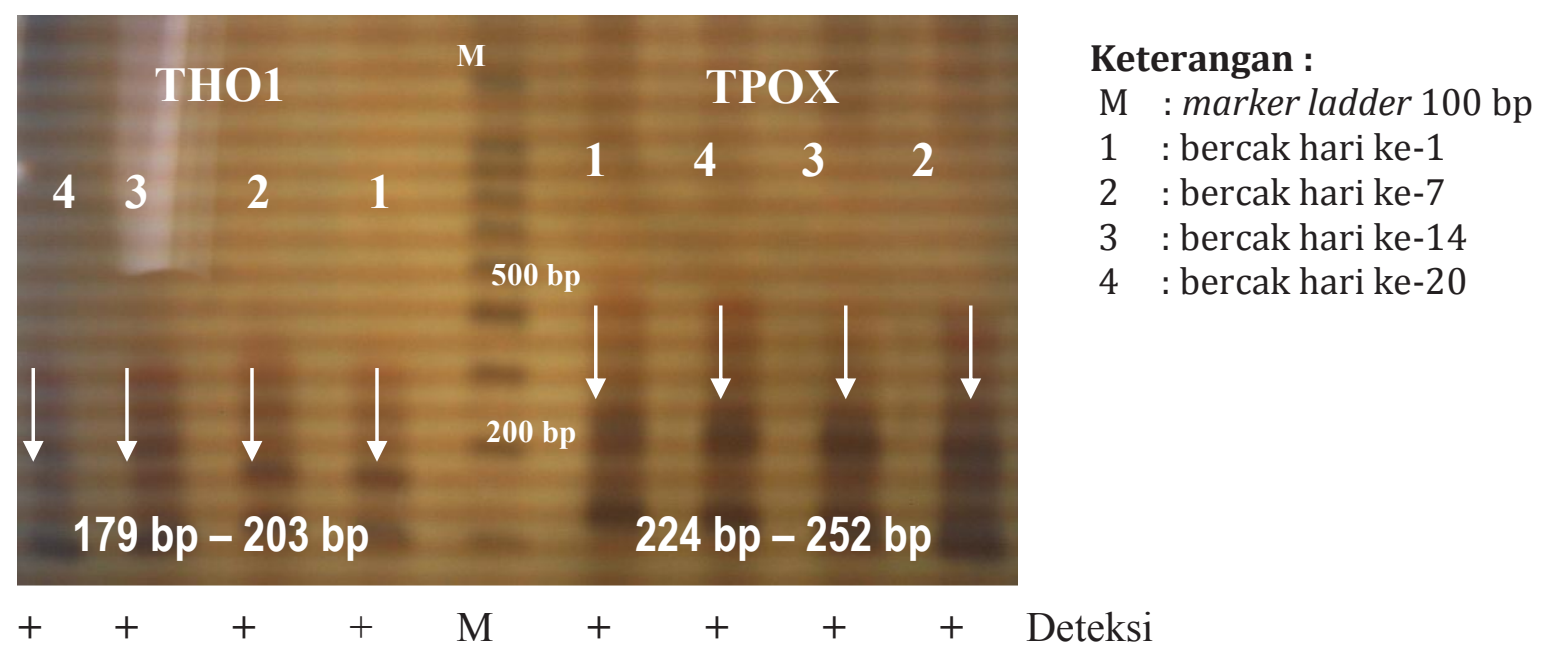

Gambar 2. Visualisasi hasil PCR lokus TPOX dan THO1 pada bercak sampel

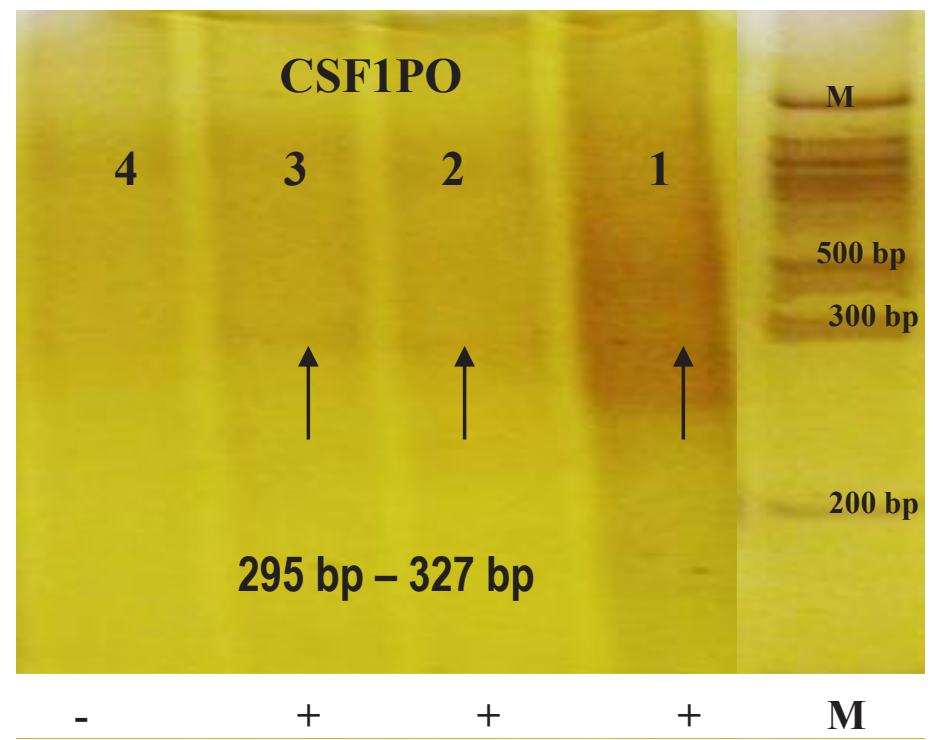

Keterangan :

M : marker ladder $100 \mathrm{bp}$

1 : bercak hari ke-1

2 : bercak hari ke-7

3 : bercak hari ke-14

4 : bercak hari ke-20

Gambar 3. Visualisasi hasil PCR lokus CSF1PO pada bercak sampel 


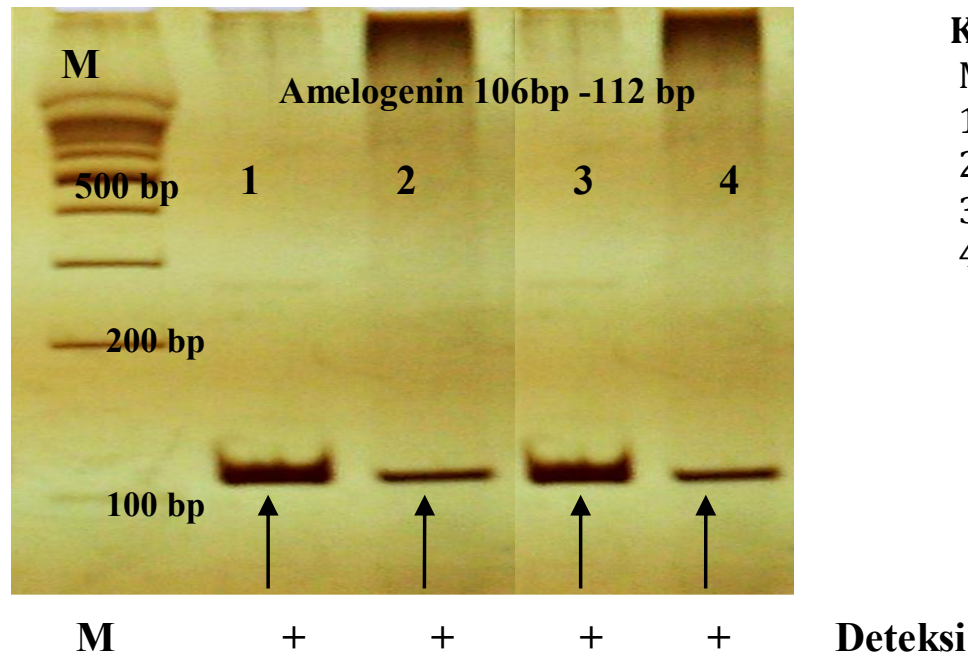

Keterangan :

M : marker ladder $100 \mathrm{bp}$

1 : bercak hari ke-1

2 : bercak hari ke-7

3 : bercak hari ke-14

4 : bercak hari ke-20

Gambar 4. Visualisasi hasil PCR lokus Amelogenin 106 bp-112 bp pada bercak sampel

si). Namun pada lama waktu paparan hari ke-20 (maksimal dalam penelitian ini) didapat hanya lokus THO1 dan TPOX semua sampelnya (100\%) nampak pita/band-nya (terdeteksi), sedangkan lokus CSF1PO dan Amelogenin hanya masingmasing satu sampel (50\%) yang nampak jelas pita/band-nya, satu sampel lainnya tidak nampak pita/band-nya (tidak terdeteksi atau samarsamar). Hal ini menunjukkan bahwa pada pemeriksaan DNA bahan bercak urine melalui deteksi lokus STR (CSF1PO, TH01, TPOX) didapatkan respon deteksi yang berbeda pada berbagai waktu lama paparan yang telah diberikan pada sampel bercak urine.

Disamping kadar DNA sampel, pada pemeriksaan DNA berbasis Polymerase Chain Reaction (PCR) juga dibutuhkan kualitas DNA yang mencukupi. Kualitas DNA yang dimaksud yakni bahwa DNA yang digunakan dalam analisis harus dalam kondisi yang terdegradasi. Jika DNA mengalami degradasi parah mengakibatkan primer tidak dapat menempel atau annealing pada DNA target yang akan digandakan [7]. Menurut Muladno [7], untuk mendapatkan hasil visualisasi yang adekuat dibutuhkan kemurnian DNA yang adekuat dan kadar DNA yang memadai, sehingga DNA dapat digunakan sebagai bahan pemeriksaan DNA termasuk dalam hal ini adalah identifikasi dan tes paternitas. Oleh karena itu, kualitas DNA yang bagus menjadi prasyarat fundamental bagi keberhasilan reaksi PCR secara keseluruhan. Sensitivitas PCR merupakan fungsi dari jumlah siklus dan kadar serta integritas dari DNA.

Keberhasilan deteksi lokus tersebut ditunjang oleh adanya perbedaan amplicon product, kandungan GC atau ikatan guanin-sitosin pada masing-masing lokus. Menurut Muladno [7], kandungan GC memiliki tingkat kestabilan yang tinggi terhadap denaturasi dibandingkan dengan ikatan antara adenin dan timin. Hasil perhitungan rasio kandungan GC mempunyai nilai yang bermakna. Dari lokus-lokus yang diteliti, rasio $G C$ content dalam primer diurut dari yang terendah adalah sebagai berikut: lokus CSF1PO $(42,61 \%)$, TPOX (56,25\%), dan THO1 (63,83\%). Sehingga dari penelitian didapatkan bahwa lokus THO1 maupun TPOX memiliki kemungkinan yang sama dalam keberhasilan pemeriksaan STR dibandingkan dengan lokus CSF1PO.

Disamping itu penggunaan lokus-lokus CSF1PO, THO1 dan TPOX mengingat bahwa lokuslokus tersebut merupakan salah satu lokus pertama yang dikembangkan oleh Forensic Science Service, serta lokus-lokus tersebut memiliki probabilitas kecocokan dengan perbandingan 1 dalam 50 juta [6].

Penelitian ini menggunakan analisis STR (CSF1PO, TH01, TPOX, dan amelogenin X 106 bp; 
Y 112 bp), karena pada umumnya sampel-sampel forensik yang dilakukan pemeriksaan DNA, $40 \%$ sudah mengalami degradasi atau kontaminasi [5], sehingga dengan analisis Short Tandem Repeat (STR) yang mempunyai core sequences kurang $1 \mathrm{~kb}$ (kilobase) sangat efektif dan nilai keberhasilannya cukup tinggi, terutama pada DNA yang mengalami degradasi akan terfragmented (terpotong-potong) dengan menghasilkan fragmen yang pendek-pendek.

Federal Beraue Investigation (FBI) bersinergis dengan Combined DNA Index System (CODIS) telah mendesain 16 lokus STR untuk sebagai rekomendasi dalam pemeriksaan identifikasi forensik atau paternitas. Mengenai syarat minimal jumlah lokus STR yang digunakan untuk pemeriksaan sampai saat ini belum ada kesepakatan. Ada beberapa laboratorium mensyaratkan minimal 3 lokus untuk pemeriksaan paternitas atau identifikasi DNA, di TDC Universitas Airlangga dilakukan 7-8 lokus, sedang di Jakarta [8] dilakukan 9 lokus ditambah lokus Amelogenin dalam paternity test. Nidom [9], mengatakan 5 sampai 6 lokus STR memiliki nilai perbandingan 1:100 milyard, sehingga pada prinsipnya mengenai jumlah lokus yang diperiksa adalah semakin banyak lokus yang digunakan pemeriksaan semakin baik nilai akurasinya.

Penentuan jenis kelamin secara biologi molekuler dilakukan dengan lokus amelogenin. Amelogenin adalah sebuah gen yang mengkodekan protein yang terdapat pada kromosom seks (X dan Y). Pada gen amelogenin terdapat delesi 6 bp di dalam intron 1 pada homolog $\mathrm{X}$, sehingga bila amplifikasi PCR dari area ini dengan primer, menghasilkan amplicon 106 bp dan 112 bp dari kromosom X dan Y. Diperlukan pengamatan khusus pada hasil elektroforesis untuk membedakan letak band $\mathrm{X}$ dan $\mathrm{Y}$ yang hanya $6 \mathrm{bp}$, sehingga hanya nampak band-nya tebal (XY/pria) dan tipis (XX/wanita). Karena adanya delesi 6 bp pada kromosom $X$, sehingga produk kromosom $X$ itu sendiri memainkan peran sebagai kontrol positif. Sementara itu penggunaan kromosom Y untuk tujuan forensik dibatasi oleh kurangnya penan- da-penanda polymorphic. Karena kromosom Y diwariskan dari ayah kepada anak laki-laki tanpa rekombinan, kromosom Y bukanlah variabel diantara individu-individu dan hasil-hasil dari penanda-penanda individual tidak dapat dikombinasikan dengan menggunakan kaidah produk [6].

Penelitian ini menggunakan sampel bercak urine. Urine merupakan cairan sisa yang diekskresikan oleh ginjal yang kemudian akan dikeluarkan dari dalam tubuh melalui proses urinasi. Urine terdiri dari air dengan bahan terlarut berupa sisa metabolisme seperti urea, garam pelarut dan materi organik. Pada analisis dipstick urine untuk mengetahui adanya protein darah dan nitrit dalam urine serta untuk mengetahui pH. Analisis urine mikroskopik adalah studi urine dengan mikroskop untuk mendeteksi adanya bakteri, sel darah merah, sel darah putih dan sel epitel. Sel epitel tersebut merupakan sel yang menyusun permukaan dinding bagian dalam ginjal dan saluran kencing (terdapat 3 jenis sel epitel: skuamosa, transisi, dan sel tubulus ginjal), sehingga normal bila sel-sel tersebut terdeteksi dalam urine. Sel-sel epitel hampir selalu ada dalam urine, apalagi yang berasal dari kandung kemih (vesica urinary), urethra dan vagina. Pada bercak urine, cairan urine akan hilang akibat evaporasi sedangkan sel-sel tersebut akan menempel pada serat-serat benang kain. Bercak urine diletakkan pada suhu kamar selama maksimal 20 hari (sesuai KUHAP, lama masa penahanan dalam proses penyidikan). Dalam penelitian ini menunjukkan bahwa lingkungan berpengaruh terhadap kadar DNA. Seperti diketahui faktor lingkungan seperti halnya kelembaban serta temperatur lingkungan sangatlah berpengaruh terhadap kondisi DNA yang digunakan sebagai bahan identifikasi DNA di bidang forensik, sebagaimana pada pemeriksaan DNA di bidang lainnya.

\section{Kesimpulan}

Dari hasil dan pembahasan penelitian ini dapat disimpulkan bahwa faktor eksternal yakni 
lingkungan dan lama waktu penyimpanan mempengaruhi kuantitas dan kualitas DNA dari bercak urine pada pakaian, namun masih dapat menjadi bahan alternatif dalam identifikasi forensik. Didapatkan pola pemetaan urutan keberhasilan dari lokus STR adalah CSF1PO, TPOX dan THO1. Hal ini sesuai dengan rasio GC content masingmasing. Hal ini sesuai dengan perhitungan rasio GC content THO1 dan TPOX memiliki nilai relatif sama yakni TPOX (56,25\%), THO1 (63,83\%), jika dibandingkan dengan CSF1PO yakni 42,61\%. Terdapat kemampuan lokus STR (THO1 \& TPOX) 100\% (semua sampel) masih bisa mendeteksi DNA bercak urine pada sampai hari ke-20, sedangkan lokus CSF1PO dan amelogenin 106 bp-112 bp hanya 50\% sampel yang masih bisa mendeteksi DNA bercak urine.

\section{Daftar Pustaka}

1. Idries AM. Pedoman ilmu kedokteran forensik. Edisi pertama. Jakarta: Penerbit Binarupa Aksara; 1997.

2. Notosoehardjo I. Isolasi tulang dan gigi. Loka- karya Metodologi Laboratorium Biologi Molekuler; 2000, hal 2-6.

3. Notosoehardjo I, Kuntaman. Teori dasar dan penerapan praktis PCR. TDC Universitas Airlangga; 2002, hal 1-11.

4. Watson. Molecular biology of the gene, $4^{\text {th }}$ ed. Cummings Publishing Company, Inc.; 1986.

5. Notosoehardjo I. Penentuan jenis kelamin berdasarkan pemeriksaan DNA dan antropometri tulang. Disertasi Doktor, Universitas Airlangga, Surabaya; 1999.

6. Butler JM. STR Analysis for human testing, STR Typing. Current protocols in Human Genetic Unit.14.8; 2001: 1-37.

7. Muladno. Seputar teknologi rekayasa genetik, Edisi pertama. Bogor: Pustaka; 2002.

8. Atmaja DS. Peranan sidik jari DNA dalam bidang forensik, Seminar Nasional Aplikasi DNA Finger Printing dalam Bidang Kedokteran, 29 Agustus 2005, PS Bioteknologi UGM.

9. Nidom CA. Teknik biomolekuler untuk penentuan 'DNA profil', kumpulan makalah seminar sehari tentang Tes Paternitas ditinjau dari berbagai aspek, TDC UNAIR, November 2005. 